TABLE VI-Sex ratio by gestation in 169631 deliveries in Scotland, 1973-79. (SMR 11 data, known gestation only)

\begin{tabular}{lcccccccccccccc}
\hline & Gestation (weeks): & $\leqslant 27$ & $28-30$ & $31-2$ & $33-4$ & 35 & 36 & 37 & 38 & 39 & 40 & 41 & $42+$ & Total \\
\hline Male births & 97 & 344 & 415 & 834 & 785 & 1991 & 3488 & 9618 & 18467 & 33106 & 15461 & 3351 & 87957 \\
Female births & 71 & 250 & 342 & 711 & 683 & 1674 & 2904 & 8261 & 16792 & 31652 & 15292 & 3042 & 81674 \\
Sex ratio (male per 100 female births) & $136 \cdot 6$ & $137 \cdot 6$ & $121 \cdot 3$ & $117 \cdot 3$ & $114 \cdot 9$ & $118 \cdot 9$ & $120 \cdot 1$ & 116.5 & $110 \cdot 0$ & $104 \cdot 6$ & $101 \cdot 1$ & $110 \cdot 1$ & $107 \cdot 7$ \\
\hline
\end{tabular}

steroids and oestrogen precursors which may affect the onset of labour. The cumulative percentage according to weeks of gestational age of boys born in a given birthweight category was more similar to the cumulative percentage of girls born in the adjacent lighter birthweight category than the cumulative percentage born in the same birthweight category. Thus at any given gestational age there appeared to be a fetal weight which was, by itself, able to trigger the spontaneous onset of labour. Alternatively, specific hormonal differences between male and female fetuses, such as increased male testosterone concentrations, ${ }^{6}$ may have been responsible. Although we do not know why girls are more likely to be induced, it may be because they are more likely to remain undelivered after term.

Female babies are more likely to present by the breech and are therefore over-represented among breech births. Easier delivery due to lower birth weight seems not to be a factor. When the fetal presentation is cephalic, however, female babies are much more likely to be delivered spontaneously whereas male babies are more likely to deliver either by forceps or by caesarean section. There has in recent years been a policy of operative or instrumental delivery in preterm births, but this is not the reason for the higher forceps and caesarean section rate in boys, although they do deliver preterm more often. Cephalopelvic disproportion may occur more often because of the greater weight of male babies or the male fetal hormonal contribution to the progress of labour may be less effective than the female, thus resulting in maternal uterine dysfunction. Furthermore, male babies may show fetal distress in labour more often or more severely than female. This seems the most likely explanation and is consistent with the fact that neonatal mortality from difficult labour is higher in boys, ${ }^{7}$ as is stillbirth from difficult labour. This cause of death showed a higher sex ratio than any other cause of stillbirth. ${ }^{8}$

\section{References}

${ }^{1}$ Butler NR, Bonham DG. Perinatal mortality. Edinburgh and London: E and S Livingstone Ltd, 1963.

2 Chamberlain R, Chamberlain G, Howlett B, Claireux A. The first week of life. British births 1970, vol 1. London: Heinemann, 1975.

${ }^{4}$ Samphier M, Thompson B. In: Mednick SA, Baert AE, eds. The Aberdeen maternity and neonatal data bank in prospective longitudinal research. Oxford: Oxford University Press, 1981.

5 Information Services Division. Birthweight, head circumference and length by gestational age (Scotland) 1973-1979. Edinburgh: Scottish Health Service, Common Services Agency, 1981.

${ }^{6}$ Abramovich DR. Interrelation of fetus and amniotic fluid. In: Wynn RM, ed. Obstetrics and Gynaecology Annual. Vol 10. 1981.

7 Hammoud EI. Sex differentials in mortality. An enquiry with reference to the Arab countries and others. World Health Stat Rep 1977;30 174-206.

${ }^{8} \mathrm{McK}$ eown $\mathrm{T}$, Lowe $\mathrm{CR}$. The sex ratio of stillbirths related to cause and duration of gestation. Hum Biol 1951 ;23:41-60.

(Accepted 1 fune 1982)

\title{
Blood pressure and contraceptive use
}

\author{
KAY-TEE KHAW, W S PEART
}

\begin{abstract}
In a survey of 461 women routinely attending family planning clinics those taking oral contraceptives had significantly higher mean systolic and diastolic blood pressures than those using non-hormonal contraception. There appeared to be a dose-response relation of blood pressure to the progestogen component of two oral contraceptives with an identical $30 \mu \mathrm{g}$ ethinyloestradiol component. This supports the idea that the progestogen as well as the oestrogen component has an aetiological role in the rise in blood pressure. There was a significant correlation of blood pressure with duration of current use of oral contraceptive but not with total duration of use. There was also a significant negative correlation of blood pressure with time since oral contraceptives were last taken, and women who had stopped using oral contraceptives over a month previously
\end{abstract}

St Mary's Hospital Medical School, London W2 1PG

KAY-TEE KHAW, MSC, MRCP, Wellcome research fellow, department of epidemiology

W S PEART, FRCP, FRS, professor of medicine had similar blood pressures to those who had never taken them. In women taking oral contraceptives those who had either a history of hypertension in pregnancy or a family history of hypertension had significantly higher mean blood pressures than those who did not. Both systolic and diastolic blood pressures correlated independently with weight and body mass index, but controlling for the effect of this and age did not affect the above relations. No significant differences in mean blood pressures were found between different ethnic groups, and there was no relation of blood pressure to reported marital state, social class, parity, smoking, or alcohol use.

Any oral contraceptive that has a less adverse effect on blood pressure has implications for general prescribing policy; thus even small differences in the progestogen contents of low-dose oestrogen pills may be important.

\section{Introduction}

It is generally accepted from cross-sectional and longitudinal studies that use of oral hormonal contraceptives is aetiologically associated with a rise in blood pressure. ${ }^{1-8}$ The precise nature of this relation, however, is not clear: neither the component in the oral contraceptive responsible nor any groups who might be 
most at risk of a rise in blood pressure have been convincingly demonstrated. Most studies were done when oral contraceptives with an oestrogen dose of $50 \mu \mathrm{g}$ or more were commonly prescribed. The oestrogen component has been associated with increased morbidity, particularly from vascular events, and is believed to be the component responsible for the rise in blood pressure. After a recommendation in 1969 by the Committee of Safety of Medicines the oestrogen dose in oral contraceptives was lowered, and in the past few years oral contraceptives containing $30 \mu \mathrm{g}$ oestrogen have been routinely preferred. One study ${ }^{6}{ }^{6}$ however, found that women using contraceptives containing $30 \mu \mathrm{g}$ oestrogen had similar blood pressures to those using contraceptives containing $50 \mu \mathrm{g}$ oestrogen, and the authors suggested that the progestogenic component might be important in raised blood pressure, though another study did not support this. ${ }^{7}$

There is little evidence that there are any subgroups who might be particularly susceptible to the hypertensive effect of oral contraceptives, though possibly women who have a history of phase five (disappearance of sounds). The mean of the two values was used for analysis. Height and weight were measured with the subjects wearing light clothing without shoes. Blood pressure was recorded by one observer trained in blood pressure measurements using a standard tape recording. ${ }^{9}$

\section{Results}

BLOOD PRESSURE, AGE, WEIGHT, AND CONTRACEPTIVE USE

The women were divided into two age groups-those aged under 35 and those aged 35 and over-because of differences in prescribing policy for oral contraception in women over 35 . Women under 35 using oral contraception had significantly higher mean systolic and diastolic blood pressures than those using non-hormonal forms of contraception (table I). Mean ages were similar (24.2 years in those taking oral contraception, 25.3 years in those using non-hormonal contraception). In the group aged 35 and over no significant differences in blood pressure were found; this was probably due to selection differences (see below).

TABLE I-Mean (and SD) blood pressure, weight, and pulse rate by age group and contraceptive use

\begin{tabular}{|c|c|c|c|c|c|c|}
\hline \multirow{2}{*}{$\begin{array}{l}\text { Age } \\
\text { (years) }\end{array}$} & \multirow{2}{*}{$\begin{array}{c}\text { Contraceptive } \\
\text { use }\end{array}$} & \multirow{2}{*}{$\mathbf{n}$} & \multicolumn{2}{|c|}{ Blood pressure (mm Hg) } & \multirow{2}{*}{$\begin{array}{c}\text { Weight } \\
(\mathrm{kg})\end{array}$} & \multirow{2}{*}{$\begin{array}{c}\text { Pulse rate } \\
\text { (beats/min) }\end{array}$} \\
\hline & & & Systolic & Diastolic & & \\
\hline$<35$ & $\left\{\begin{array}{l}\text { Not oral } \\
\text { Oral }\end{array}\right.$ & $\begin{array}{l}176 \\
222\end{array}$ & $\left.\begin{array}{l}109 \cdot 3(11 \cdot 4) \\
113.0(12 \cdot 1)\end{array}\right\} *$ & $\left.\begin{array}{ll}70 \cdot 1 & (8 \cdot 8) \\
72 \cdot 7 & (9 \cdot 9)\end{array}\right\} *$ & $\begin{array}{ll}59 \cdot 4 & (9 \cdot 9) \\
58.4 & (8 \cdot 6)\end{array}$ & $\begin{array}{l}80.3(11 \cdot 8) \\
79.6(10.8)\end{array}$ \\
\hline$\geqslant 35$ & $\left\{\begin{array}{l}\text { Not oral } \\
\text { Oral }\end{array}\right.$ & $\begin{array}{l}41 \\
22\end{array}$ & $\begin{array}{l}118 \cdot 4(20 \cdot 7) \\
116 \cdot 1(16 \cdot 2)\end{array}$ & $\begin{array}{l}77 \cdot 2(11 \cdot 2) \\
76.8(12 \cdot 5)\end{array}$ & $\begin{array}{l}63 \cdot 2(10 \cdot 7) \\
62.7(15 \cdot 8)\end{array}$ & $\begin{array}{l}77.4(12.0) \\
78.9(13.7)\end{array}$ \\
\hline
\end{tabular}

${ }^{*} \mathrm{p}<0.05$.

TABLE II-Mean (and SD) blood pressure by type of oral contraceptive, duration of current use, and when oral contraceptive last used in women aged under 35

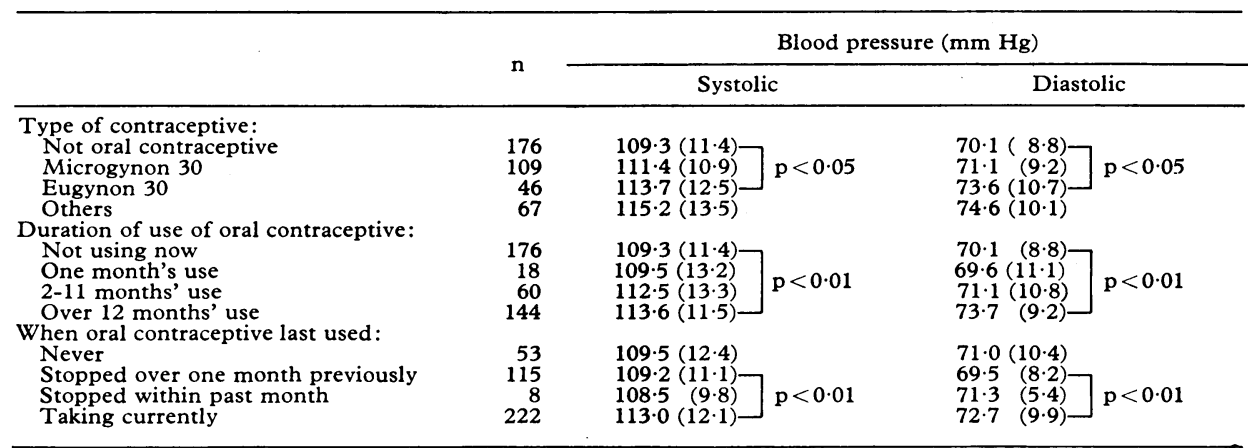

high blood pressure during pregnancy might be more likely to respond to the hormonal stimulus of the oral contraceptive with a greater rise in blood pressure than women who have no such history. Similarly, women who might be thought to be predisposed to higher blood pressures such as those with a family history of hypertension or black women might also be expected to have higher blood pressures when taking oral contraceptives.

In the present study we aimed to examine blood pressure and its association with these and other factors in an unselected population for whom $30 \mu \mathrm{g}$ oestrogenic oral contraceptives were routinely prescribed.

\section{Study population and methods}

Altogether 461 women routinely attending two family planning clinics during May 1981 were seen. They were told that a survey of normal women attending the clinic was being undertaken and were first given a standard questionnaire. There were no refusals. After five minutes' rest two measurements of blood pressure made with a random zero sphygmomanometer and pulse rate were recorded from the right arm with the subject seated. Diastolic pressure was recorded at
Overall, there was a significant correlation of both systolic and diastolic pressures with weight (systolic pressure $r=0.34, p<0.001$; diastolic pressure $r=0.37, p<0.001$ ), and partial correlations of systolic blood pressure with weight controlling for diastolic pressure and of diastolic pressure with weight controlling for systolic pressure were both significant $(p<0.002)$, suggesting that both pressures have independent relations with weight. Correlation coefficients were no better for body mass index than for weight alone, so subsequent analyses were confined to weight. There were also significant correlations of pulse rate with both systolic and diastolic pressures independent of weight. Adjustment for the effects of weight and pulse rate, however, did not account for the differences in blood pressure between those taking oral contraceptives and those using non-hormonal contraception, and table I shows no significant differences in mean weights or pulse rates between the two groups.

\section{BLOOD PRESSURE AND TYPE AND DURATION OF CONTRACEPTION}

The effects of different formulations of oral contraceptives were examined in the women aged under 35 (table II). The two formulations most commonly and routinely prescribed were Microgynon 30 (ethinyloestradiol $30 \mu \mathrm{g}$, levonorgestrel $150 \mu \mathrm{g}$ ) and Eugynon 30 
(ethinyloestradiol $30 \mu \mathrm{g}$, levonorgestrel $250 \mu \mathrm{g}$ ). Numbers were too small and reasons for use too selective for other formulations to be analysed separately. Both systolic and diastolic mean blood pressures were higher in the group taking Eugynon 30 compared with women not using oral contraceptives, and mean pressures in the group taking Microgynon 30 were in between.

There was no correlation of blood pressure with total duration of oral contraceptive use ever, but there was a significant correlation of both systolic and diastolic pressures with duration of current oral contraceptive use, and mean blood pressures were higher in those who had been taking oral contraceptives continuously for over 12 months compared with those who had been taking them for a month or less (table II) and those not using oral contraception. Blood pressures were also inversely correlated with time since oral contraceptives were last taken, and mean pressures of those who had stopped oral contraception more than a month previously were simi- in pregnancy with systolic and diastolic blood pressures $(p<0.001)$ and family history of hypertension with systolic blood pressure $(\mathrm{p}<$ 0.05).

\section{REASONS FOR CHOICE OF TYPE OF CONTRACEPTION}

Women not using oral contraception and women who had changed the brand of oral contraceptive were asked for their reasons. Women who had never taken oral contraceptives because of hypertension had significantly higher mean systolic blood pressures than women who had stopped for reasons such as nausea, weight gain, or other medical conditions as well as women who had chosen non-hormonal methods for social reasons such as preference (table V). Diastolic blood pressures were also higher, though not significantly so. Similarly, in the group using oral contraceptives women who had changed brands because of

TABLE III-Mean (and SD) blood pressure $(\mathrm{mm} \mathrm{Hg}$ ) by age, contraceptive use, and history of hypertension in pregnancy

\begin{tabular}{|c|c|c|c|c|c|c|}
\hline & \multicolumn{2}{|c|}{ Nulliparous women } & \multicolumn{2}{|c|}{ Pregnancy without hypertension } & \multicolumn{2}{|c|}{ Pregnancy with hypertension } \\
\hline & $\mathrm{n}$ & Blood pressure & $\mathrm{n}$ & Blood pressure & $\mathrm{n}$ & Blood pressure \\
\hline & \multicolumn{6}{|c|}{ Systolic blood pressure } \\
\hline $\begin{array}{l}\text { Age }<35 \text { years: } \\
\text { Not using oral contraceptive }\end{array}$ & 120 & $109.9(11.8)$ & 44 & $106 \cdot 4(9 \cdot 8)^{*}$ & 12 & $113.1(10.4)^{*}$ \\
\hline $\begin{array}{l}\text { Using oral contraceptive } \\
\text { A }\end{array}$ & 181 & $113.4(11.7)$ & 33 & $109 \cdot 4(14 \cdot 0)^{* *}$ & 8 & $119.6(8.9)^{* *}$ \\
\hline \multirow[t]{2}{*}{$\begin{array}{l}\text { Age } \geqslant 35 \text { years: } \\
\text { Not using oral contraceptive } \\
\text { Using oral contraceptive }\end{array}$} & ${ }_{11}^{7}$ & $\begin{array}{l}118.3(21 \cdot 6) \\
116.9(15 \cdot 1)\end{array}$ & $\begin{array}{r}23 \\
9\end{array}$ & $\begin{array}{l}113 \cdot 0(15 \cdot 2) \\
112 \cdot 7(18 \cdot 2)\end{array}$ & $\begin{array}{r}11 \\
2\end{array}$ & $\begin{array}{l}129.9(26.5) \\
127.5(13.4)\end{array}$ \\
\hline & \multicolumn{6}{|c|}{ Diastolic blood pressure } \\
\hline $\begin{array}{l}\text { Age } \\
\text { Not using oral contraceptive } \\
\text { Using oral contraceptive }\end{array}$ & $\begin{array}{l}120 \\
181\end{array}$ & $\begin{array}{ll}69 \cdot 9 & (9 \cdot 0) \\
72 \cdot 8 & (9 \cdot 9)\end{array}$ & $\begin{array}{l}44 \\
33\end{array}$ & $\begin{array}{l}69 \cdot 9(8 \cdot 5) \\
70 \cdot 4(10 \cdot 4)^{* *}\end{array}$ & $\begin{array}{r}12 \\
8\end{array}$ & $\begin{array}{ll}72 \cdot 4 & (8 \cdot 1) \\
78 \cdot 5 & (6 \cdot 9)^{* *}\end{array}$ \\
\hline $\begin{array}{l}\text { Age } \geqslant 35 \text { years: } \\
\text { Not using oral contraceptive } \\
\text { Using oral contraceptive }\end{array}$ & $\begin{array}{r}7 \\
11\end{array}$ & $\begin{array}{l}71.3(7.4) \\
74.4(13.9)\end{array}$ & $\begin{array}{r}23 \\
9\end{array}$ & $\begin{array}{l}73 \cdot 4(6 \cdot 0) \\
77 \cdot 9(12 \cdot 8)\end{array}$ & $\begin{array}{r}11 \\
2\end{array}$ & $\begin{array}{l}89.1(13.3) \\
84.5(0.7)\end{array}$ \\
\hline
\end{tabular}

Pregnancy without hypertension $v$ pregnancy with hypertension: ${ }^{*} \mathrm{p}<0.05 ;{ }^{* *} \mathrm{p}<0.02$.

TABLE IV-Mean (and SD) blood pressure ( $\mathrm{mm} \mathrm{Hg}$ ) by age, contraceptive use, and family history of hypertension

\begin{tabular}{|c|c|c|c|c|c|c|}
\hline & \multicolumn{2}{|c|}{ Unknown family history } & \multicolumn{2}{|c|}{ No family history } & \multicolumn{2}{|c|}{ Family history } \\
\hline & $\mathrm{n}$ & Blood pressure & $\mathrm{n}$ & Blood pressure & $\mathrm{n}$ & Blood pressure \\
\hline & \multicolumn{6}{|c|}{ Systolic blood pressure } \\
\hline $\begin{array}{l}\text { Age }<35 \text { years: } \\
\text { Not using oral contraceptives } \\
\text { Using oral contraceptives }\end{array}$ & $\begin{array}{r}4 \\
10\end{array}$ & $\begin{array}{l}101 \cdot 5(9 \cdot 5) \\
112 \cdot 8(13 \cdot 1)\end{array}$ & $\begin{array}{l}128 \\
163\end{array}$ & $\begin{array}{l}108 \cdot 7(10 \cdot 7) \\
112 \cdot 0(11 \cdot 7)^{*}\end{array}$ & $\begin{array}{l}44 \\
49\end{array}$ & $\begin{array}{l}111.6(13 \cdot 1) \\
116.3(12 \cdot 7)^{*}\end{array}$ \\
\hline \multirow[t]{2}{*}{$\begin{array}{l}\text { Not using oral contraceptives } \\
\text { Using oral contraceptives }\end{array}$} & 1 & $138 \quad(0)$ & $\begin{array}{l}27 \\
13\end{array}$ & $\begin{array}{l}112.0(12.7) \\
111.9(13.5)\end{array}$ & $\begin{array}{r}13 \\
9\end{array}$ & $\begin{array}{l}130 \cdot 2(28 \cdot 3) \\
122 \cdot 2(18 \cdot 6)\end{array}$ \\
\hline & \multicolumn{6}{|c|}{ Diastolic blood pressure } \\
\hline $\begin{array}{l}\text { Not using oral contraceptives } \\
\text { Using oral contraceptives } \\
\text { Age } \geqslant 35 \text { years: }\end{array}$ & $\begin{array}{r}4 \\
10\end{array}$ & $\begin{array}{ll}68 \cdot 8 & (4 \cdot 0) \\
72 \cdot 4 & (8 \cdot 9)\end{array}$ & $\begin{array}{l}128 \\
163\end{array}$ & $\begin{array}{ll}69 \cdot 7 & (8 \cdot 4) \\
72 \cdot 2 & (9 \cdot 8)\end{array}$ & $\begin{array}{l}44 \\
49\end{array}$ & $\begin{array}{l}71 \cdot 2(10 \cdot 3) \\
74 \cdot 4(10 \cdot 5)\end{array}$ \\
\hline $\begin{array}{l}\text { Not using oral contraceptives } \\
\text { Using oral contraceptives }\end{array}$ & 1 & $(0)$ & $\begin{array}{l}27 \\
13\end{array}$ & $\begin{array}{l}73 \cdot 7(5 \cdot 5) \\
73 \cdot 2(12 \cdot 4)\end{array}$ & $\begin{array}{r}13 \\
9\end{array}$ & $\begin{array}{l}83 \cdot 7(16 \cdot 4) \\
82 \cdot 0(12 \cdot 0)\end{array}$ \\
\hline
\end{tabular}

No family history of hypertension $v$ family history: ${ }^{*} \mathrm{p}<0 \cdot 05$.

lar to those of women who had never taken oral contraception and significantly lower than those of women who were currently taking oral contraceptives. The significant relations between blood pressure and type of oral contraceptive, duration of current use, and time since oral contraceptives were last taken were confirmed by analysis of variance taking into account the effects of age and weight $(p<0.02$ in all cases).

HISTORY OF HYPERTENSION IN PREGNANCY AND FAMILY HISTORY OF HYPERTENSION

Mean systolic and diastolic blood pressures were significantly higher in women under 35 using oral contraceptives who reported having had hypertension in pregnancy compared with women who reported having had a pregnancy free of hypertension (table III). Mean systolic blood pressure was also significantly higher in women under 35 using oral contraceptives who had a family history of hypertension compared with those who did not (table IV). Analysis of variance taking into account the effects of age, weight, and contraceptive use confirmed the significant relations between history of hypertension hypertension had significantly higher blood pressures than those who had changed brands for either non-specific or other medical reasons. This was true also of women who had changed to Microgynon 30 from Eugynon 30.

\section{OTHER FACTORS}

There were no significant differences in mean systolic or diastolic pressure according to contraceptive use between different ethnic groups, in particular between Caucasian and black women (table VI); there was also no relation between blood pressure and marital state, social class, parity, smoking, or alcohol use.

\section{Discussion}

We undertook this survey in an area where family planning clinics serve a large cross-section of the population and are open to all and all contraceptive supplies are free. Our findings con- 
TABLE v-Mean (and SD) blood pressures ( $\mathrm{mm} \mathrm{Hg}$ ) according to reason for not taking oral contraceptives or for changing type of contraceptive

\begin{tabular}{|c|c|c|c|c|c|c|}
\hline \multirow[b]{2}{*}{ Reasons } & \multicolumn{3}{|c|}{ Not using oral contraception } & \multicolumn{3}{|c|}{ Using oral contraception } \\
\hline & $\mathrm{n}$ & Systolic & Diastolic & $\mathrm{n}$ & Systolic & Diastolic \\
\hline $\begin{array}{l}\text { Age }<35 \text { years: } \\
\text { None or social } \\
\text { Other medical } \\
\text { Hypertension }\end{array}$ & $\begin{array}{r}57 \\
114 \\
5\end{array}$ & $\left.\begin{array}{l}109.8(14.0) \\
108.5(9.8) \\
119.6(7.1)\end{array}\right\} \mathrm{p}<0.01$ & $\begin{array}{ll}70 \cdot 6 & (9 \cdot 4) \\
69 \cdot 7 & (8 \cdot 6) \\
72 \cdot 0 & (6 \cdot 0)\end{array}$ & $\begin{array}{r}196 \\
17 \\
9\end{array}$ & $\left.\begin{array}{l}112.7(12.2) \\
111.3(9.9) \\
123.3\end{array}\right\} \Rightarrow p<0.01$ & $\left.\begin{array}{ll}72 \cdot 3 & (9.9) \\
71 \cdot 5 & (8 \cdot 7) \\
82 \cdot 1 & (8.9)\end{array}\right\} \sqsupset \mathrm{p}<0.01$ \\
\hline $\begin{array}{l}\text { Age } \geqslant 35 \text { years: } \\
\text { None or social } \\
\text { Other medical } \\
\text { Hypertension }\end{array}$ & $\begin{array}{r}5 \\
32 \\
4\end{array}$ & $\begin{array}{l}110 \cdot 0(12 \cdot 3) \\
117.3(18 \cdot 0) \\
137.5(39 \cdot 1)\end{array}$ & $\begin{array}{l}74 \cdot 0(11 \cdot 8) \\
77 \cdot 0(10 \cdot 0) \\
83 \cdot 3(19 \cdot 3)\end{array}$ & $\begin{array}{r}20 \\
1 \\
1\end{array}$ & $\begin{array}{l}115 \cdot 6(16 \cdot 7) \\
114 \cdot 0(0) \\
129 \cdot 0(0)\end{array}$ & $\begin{array}{l}76 \cdot 4(13 \cdot 0) \\
71 \cdot 0(0) \\
9 \cdot 0(0)\end{array}$ \\
\hline
\end{tabular}

TABLE VI-Mean (SD) blood pressures ( $m m \mathrm{Hg}$ ) by age, ethnic group, and contraceptive use

\begin{tabular}{|c|c|c|c|c|c|c|c|}
\hline \multirow[b]{2}{*}{ Age } & \multirow[b]{2}{*}{ Ethnic group } & \multicolumn{3}{|c|}{ Non-oral contraception } & \multicolumn{3}{|c|}{ Oral contraception } \\
\hline & & $\mathbf{n}$ & Systolic & Diastolic & $\mathbf{n}$ & Systolic & Diastolic \\
\hline$<35$ years & $\left\{\begin{array}{l}\text { Caucasian } \\
\text { Black } \\
\text { Other }\end{array}\right.$ & $\begin{array}{r}22 \\
21 \\
33\end{array}$ & $\begin{array}{l}110.5(11.4) \\
108.9(13.3) \\
105.1 \quad(9.0)\end{array}$ & $\begin{array}{l}69.5(8.9) \\
73.6(10.2) \\
69.8(6.9)\end{array}$ & $\begin{array}{r}176 \\
21 \\
25\end{array}$ & $\begin{array}{l}113.8(11.6) \\
110.3(13.9) \\
109.6(13.7)\end{array}$ & $\begin{array}{l}72.5(9.5) \\
73.4(11.4) \\
73.1(11.9)\end{array}$ \\
\hline$\geqslant 35$ years & $\left\{\begin{array}{l}\text { Caucasian } \\
\text { Black } \\
\text { Other }\end{array}\right.$ & $\begin{array}{r}28 \\
8 \\
5\end{array}$ & $\begin{array}{l}117 \cdot 5(16 \cdot 3) \\
122 \cdot 4(34 \cdot 2) \\
117 \cdot 2(19 \cdot 6)\end{array}$ & $\begin{array}{l}76 \cdot 0(9 \cdot 7) \\
83.0(15 \cdot 8) \\
74.0 \quad(8 \cdot 3)\end{array}$ & $\begin{array}{r}17 \\
0 \\
5\end{array}$ & $\begin{array}{l}118.4(17.6) \\
108.6 \quad(6.9)\end{array}$ & $\begin{array}{l}76 \cdot 3(14 \cdot 2) \\
78 \cdot 2 \quad(7 \cdot 4)\end{array}$ \\
\hline
\end{tabular}

firm those of other cross-sectional studies that women using oral contraceptives have higher mean blood pressures than women using non-hormonal contraception. ${ }^{16}$ The evidence from longitudinal work ${ }^{4}$ suggests that hormonal contraception has an aetiological role in the rise in blood pressure.

The main criticism in any study of contraception is that choice of method is not random and users of oral contraceptives may differ from users of non-oral contraceptives in many ways. Any selection biases occurring, however, are most likely to minimise any differences found with respect to blood pressure: hypertension is recognised as a relative contraindication to oral contraceptive use so women who have high blood pressure are likely to be advised not to take oral contraceptives. This is supported by table $\mathrm{V}$, which shows, within the women using non-hormonal contraception, significantly higher mean pressures in those who did not take oral contraceptives because of hypertension. Any differences, therefore, are likely to be real. This bias probably also explains why in those aged over 35 no differences in blood pressure are found between women using different contraceptives: there is a general policy whereby use of oral contraceptives by women over 35 is discouraged, particularly in women who may have risk factors such as smoking or hypertension, so selection problems are particularly apparent in this group.

The oestrogenic component of the oral contraceptive is generally thought to be responsible for the rise in blood pressure: Briggs and Briggs? did not show any rise in blood pressure over three years in women taking a $30 \mu \mathrm{g}$ oestrogen contraceptive, whereas a rise occurred in women taking a $50 \mu \mathrm{g}$ contraceptive. Weir ${ }^{10}$ showed a reduction in mean pressure when a group of women with hypertension taking a $50 \mu \mathrm{g}$ oestrogen pill were changed to $30 \mu \mathrm{g}$ oestrogen. Meade et al ${ }^{6}$ however, found higher mean blood pressures in 15 women taking $30 \mu \mathrm{g}$ compared with 28 women taking $50 \mu \mathrm{g}$ oral contraceptives and attributed this to the different progestogenic components. The study was on small numbers, however, and used age-corrected pressures, and selection bias was not adequately ruled out.

In our study the two contraceptives routinely prescribed were Microgynon 30 and Eugynon 30. They have an identical oestrogen dose-30 $\mu \mathrm{g}$ ethinyloestradiol-and differ only in the dose of progestogen $(150 \mu \mathrm{g}$ levonorgestrel in Microgynon 30 and 250 $\mu \mathrm{g}$ levonorgestrel in Eugynon 30). The differences in mean blood pressure suggested a dose-response relation with the levonorgestrel component, and this was confirmed by analysis of variance. As discussed above, any selection bias would have minimised the association as women with high blood pressure were more likely to have been changed to the lower-dose Microgynon 30 from Eugynon 30. Thus the progestogen component in a low-dose oestrogen pill appears to have an appreciable effect on blood pressure.

This study showed a positive correlation between duration of current use of oral contraceptive and both systolic and diastolic pressures. This is consistent with the finding of a longitudinal study that blood pressure increased with the time for which an oral contraceptive was taken. ${ }^{4}$ There was no relation with total cumulative duration of oral contraceptive use. In a cross-sectional study a possible relation might be obscured by imperfect recall or history of total duration. It is unlikely, however, that accuracy of information should differ greatly between duration of current use and total duration of use. Another suggestion is that blood pressure may revert quite quickly during periods when contraceptive use is stopped. This is supported by the findings that women who had stopped taking oral contraceptives over a month previously had similar blood pressures to those who had never taken oral contraceptives and that both groups had lower blood pressures than current users. This implies that changes in blood pressure related to oral contraceptives are reversible in a short time and is again consistent with findings in some longitudinal studies, ${ }^{4}$ though not in others. ${ }^{11}$

Two factors have been suggested that might make women susceptible to the blood-pressure raising effect of oral contraceptives-namely, a history of hypertension during pregnancy and a family history of hypertension. Most studies based on contraceptive clinics have found no significant relations, ${ }^{45}$ though in Kentucky highest systolic blood pressures were found in women who had had hypertension during pregnancy and were taking the oral contraceptive. ${ }^{12}$ In our study, among women using oral contraceptives those with either a history of hypertension during pregnancy or a family history of hypertension had significantly higher blood pressures than those without. In a cross-sectional survey it is impossible to say whether this observation was because this group had a higher basal pressure to begin with and experienced a similar rise in blood pressure while taking oral contraceptives to that in the group without such a history, or whether they experienced a greater rise in blood pressure while taking oral contraceptives: available evidence suggests the former. Women not using oral contraceptives who had had hypertension during pregnancy or had a family history of hypertension also had higher mean pressures than those who did not, though these differences were not significant in all cases. This association is again unlikely to have been due to selection as any bias would probably have minimised the differences: women who have had hypertension during pregnancy or who have a family history of hypertension are more likely to be advised against oral contraception.

It may be hypothesised that groups who generally have higher 
distributions of blood pressure might be more susceptible to the hypertensive effects of oral contraceptives: studies in the United States found higher mean blood pressures in black compared with white adults, and in England in both factory workers ${ }^{13}$ and civil servants ${ }^{14}$ black men had higher mean blood pressures than white men. In our study, however, we found no differences between black and white women, though with the numbers available a $5 \mathrm{~mm}$ difference would have been significant. Few studies have examined the effect of different contraceptives on different ethnic groups. In 2676 black women attending a family planning clinic in Atlanta no significant differences in mean blood pressure were found between those using oral contraceptives and controls. ${ }^{15}{ }^{16}$ In our study no significant differences in systolic blood pressure were detectable, and diastolic pressures were virtually identical. Though several explanations are possible-among them selection bias-there is no evidence that black women are particularly susceptible to the hypertensive effects of oral contraceptives.

The differences in mean blood pressure documented here were small (around $5 \mathrm{~mm} \mathrm{Hg}$ ) but are of interest both in investigations of the aetiology and mechanisms of the rise in blood pressure and in terms of community impact. In a population in which a large proportion of healthy women are using oral contraceptives a small shift in the distribution of a risk factor may have a large impact on the community's overall burden of disease, ${ }^{17}$ and there is no doubt that raised blood pressure is one of the major factors in morbidity and mortality in most societies. Though different effects of oral contraceptives cannot be considered in isolation, any oral contraceptive that can be shown to have a less adverse effect on blood pressure has implications for general prescribing policy. Within this context even the small but important differences in the progestogen contents of lowdose oestrogen pills may constitute differences in risk that, though insignificant to the individual, may be of considerable importance to the community.

We thank Dr P Thompson, specialist in family planning, North-west District, and staff of Raymede and Queens Park family planning clinics.

\section{References}

${ }^{1}$ Fisch IR, Freedman SH, Myatt AV. Oral contraceptives, pregnancy and blood pressure. $\mathcal{F} A M A$ 1972;222:1507-10.

2 Royal College of General Practitioners. Oral contraception study. Effect on hypertension and benign breast disease of progestogen component in combined oral contraceptive. Lancet $1977 ; \mathrm{i}: 624$.

${ }^{3}$ Royal College of General Practitioners. Hypertension. In : Oral contraception and health. Tunbridge Wells: Pitman Medical, 1974:37-42.

4 Weir RJ, Briggs E, Mack A, Naismith L, Taylor L, Wilson E. Blood pressure in women taking oral contraceptives. Br Med f 1974;i :533-5.

${ }^{5}$ Pritchard JA, Pritchard SA. Blood pressure response to estrogen-progestin oral contraceptive after pregnancy-induced hypertension. Am $\mathcal{F}$ Obstet Gynecol 1977;129:733-9.

${ }^{6}$ Meade TW, Haines AP, North WRS, Chakrabarti R, Howard DJ, Stirling Y. Haemostatic, lipid and blood pressure profiles of women on oral contraceptives containing 50 micrograms or 30 micrograms of oestrogen. Lancet 1977 ;ii:948-51.

${ }^{7}$ Briggs M, Briggs $M$. Oestrogen content of oral contraceptives. Lancet $1977 ;$ ii $: 1233$.

${ }^{8}$ Spellacy WN, Birk SAA. Effect of intrauterine devices, oral contraceptives, estrogen and progestogens on blood pressure. Am $\mathcal{F}$ Obstet Gynecol 1972;112:912-9.

${ }^{9}$ Rose G. Standardisation of observers in blood pressure measurements. Lancet $1965 ; \mathrm{i}: 673-4$.

10 Weir RJ. Reduced hypertensive risks of low dose contraceptive steroids. In: Yamori Y, ed. Prophylactic approach to hypertensive diseases. Vol 4. New York: Raven Press, 1979;15-20.

11 Smith RW. Hypertension and oral contraception. Am $\mathcal{f}$ Obstet Gynecol $1973 ; 113: 482-7$.

12 Kotchen JM, Kotchen TA, Cottrill CM, Guthrie GP Jr, Somes G. Blood pressures of young mothers and their first children three to six years following hypertension during pregnancy. F Chron Dis 1979;32:653-9.

13 Sever PS, Peart WS, Meade TW, Davies IB, Gordon D. Ethnic differences in blood pressure with observations on noradrenaline and renin. Clin Exp Hypertens 1979;1:733-44.

14 Marmot MG, Rose G. Epidemiology of hypertension. In: Sleight $P$, Jones JV, eds. Scientific foundations of cardiology. London: Heinemann (in press).

15 Hall WD, Douglas MB, Blumenstein BA, Hatcher RA. Blood pressure and oral progestational agents. Am $\mathcal{F}$ Obstet Gynecol 1980;136:344-8.

16 Blumenstein BA, Douglas MB, Hall WD. Blood pressure changes and oral contraceptive use: a study of 2676 black women in the south eastern United States. Am $\mathcal{F}$ Epidemiol 1980;112:539-52.

17 Rose G. Strategy of prevention: lessons from cardiovascular disease. $\mathrm{Br}$ Med f $1981 ; 282: 1847-51$.

(Accepted 24 fune 1982)

\section{SHORT REPORTS}

\section{Avoidance of tracheostomy in sleep apnoea syndrome}

Obstructive sleep apnoea (the Pickwickian syndrome) as a cause of daytime hypersomnolence, intellectual deterioration, and eventual respiratory failure with cor pulmonale and death is well recognised. ${ }^{1}$ Tracheostomy may be life saving and is the treatment of choice in some centres, although other methods have been tried with limited success. ${ }^{1}$ It is, however, a drastic treatment with medical and psychological implications and if possible should be avoided.

\section{Case report}

A 37-year-old company director presented with obesity and hypersomnolence. At the age of 9 years he had developed asthma, which had troubled him only intermittently. Eighteen months before presentation he had begun to experience disturbed sleep and hypersomnolence, and his weight had increased from 83 to $121 \mathrm{~kg}$. He had consulted a neurologist and had since been taking amphetamines for a diagnosis of narcolepsy. His weight and symptoms had gradually increased. His main complaint was of irresistible somnolence, repeatedly falling asleep in the middle of important business meetings and while driving (crashing his car and injuring his daughter). He had never fallen asleep while standing up. His performance at work had deteriorated and the company was now in serious financial trouble. Associated features were morning headaches and loud snoring.

Examination disclosed no abnormality apart from drowsiness, obesity, a considerably deviated nasal septum partially blocking both nasal passages, and large tonsils. Spirometry showed moderate, reversible airways obstruction (forced expiratory volume in one second $2 \cdot 11$, vital capacity $4 \cdot 81$ ). Results of routine haematology, biochemistry, chest radiography, and electrocardiography were normal. Arterial oxygen tension was $11.5 \mathrm{kPa}(86 \mathrm{~mm} \mathrm{Hg})$ and carbon dioxide tension $5.0 \mathrm{kPa}(38 \mathrm{~mm} \mathrm{Hg})$. Overnight monitoring showed periods of obstructive apnoea during sleep producing swings of arterial oxygen saturation from $94 \%$ to $72 \%$. Arousal occurred only occasionally at the nadir of the drops in arterial oxygen saturation.

Because of the relative mildness of his apnoea and his inability to lose weight protriptyline $60 \mathrm{mg} /$ day was tried for one month but produced no benefit. Medroxyprogesterone acetate $50 \mathrm{mg}$ nightly produced initial improvement followed by an appreciable decline. These drugs have been reported as beneficial in some cases of sleep apnoea syndrome. ${ }^{1}$ Repeat overnight monitoring showed recurrent 40 -second obstructive sleep apnoeas throughout the night, accompanied by arterial oxygen desaturation to $65 \%$, arousal on each occasion, and heart rate oscillating between 85 and 125 beats/min.

Submucus resection and tonsillectomy were performed to reduce his upper airways resistance. He suffered obstructive apnoea at induction but intubation was accomplished without difficulty. No narcotics were used and the endotracheal tube was left in place for 18 hours postoperatively. Despite this he slept for long periods with intermittent nitrous oxide as the only analgesia. The next day he was fully alert; the hypersomnolence did not return.

Eighteen days later he was fully recovered. He had discovered business errors made in recent months, which he was trying to correct. Overnight monitoring showed no sleep apnoea, but snoring persisted. A tracing of arterial oxygen saturation showed small oscillations $(<2 \%)$. There werè no recurrent arousals as before. In six weeks he lost $15 \mathrm{~kg}$ in weight; the snoring subsequently disappeared. 